\title{
Contribution of Forest Production to GDP and Its Challenges in Oromia National Regional State, Ethiopia
}

\author{
Hundessa Adugna Yadeta \\ Ethiopian environment and Forest Research Institute. Addis Ababa, Ethiopia. \\ Email: hundessaa@gmail.com
}

Received: October 6, 2016; Accepted: January 14, 2016; Published: March 2, 2017

Permalink/DOI: http://dx.doi.org/10.17977/um002v9i12017p102

\begin{abstract}
This study aimed to analyze the contribution of forest production and challenges in forestry accounting. This study was conducted on the regional GDP of Oromia national regional state based on 10 years data. The result shows that market value of forest production and its contribution to GDP of Oromia showed continuous increment. Forest products are used as a source of fuel, production of timber and source of construction materials. On an average, forest production contributed about $6.10 \%$ to GDP and became the second least contributor to the GDP of Oromia. Reduction of forest coverage due to deforestation, underestimation of value of forestry products and existence of missing attributes of forestry in the SNA are the main challenges in forestry contribution to GDP of Oromia. Thus, Bureau of finance and economic development of Oromia should re-examine how economic growth can be achieved through contribution of forest production, taking awareness of existing capacity to increase growth and alleviate poverty. Resources should be directed into areas where there is adequate evidence of potential growth. This will be achieved through enhancement of conservation and wise use of forest resources so that it can contribute more to the domestic income directly and indirectly through its contribution to other sectors.
\end{abstract}

Keywords: GDP, Contribution, Oromia, Forest Production, Deforestation, Underestimation

JEL Classification: R11, Q56

\section{INTRODUCTION}

Forestry has manifold contributions towards the welfare of mankind. It provides a variety of products and services to the livelihood of the human beings. The raw materials for housing and wood products are extracted from the forest. The multiple uses of forest resources have been recognized from the advent of civilization (Kamal, 2010). In many parts of the world, wood is an important fuel. Paper products are derived from wood fiber. Trees cleanse the air by absorbing carbon dioxide and adding oxygen. Forests provide shelter and sanctuary for wildlife and they play an important role in maintaining the watersheds that supply much of our drinking water (Tietenberg et al, 2012).

Forest and non-forest products can contribute to the gross domestic product (GDP) through the creation and maintenance of wood plantations, creation of employment, use of sustainable harvesting practices, improvement in value addition and quality assurance certification. The forestry sector plays several important economic roles - by earning foreign currency mainly from 
export of non-wood forest products, by providing energy and wood products, by generating formal and informal employment, and by providing environmental services that support the sustainable operation of other sectors. These measures would improve a country's trade balance, while at the same time increasing the interest of those employed in the sector as well as communities to partner with the private sector in order to increase investment in the sector. Forestry products in the country are categorized into different subsectors, each contributing to the GDP. The timber production subsector represents the main source of raw material that constitutes most of the total national wood production (FAO, 2006).

Trees, when harvested, provide a salable commodity, but left standing they are a capital good, In Ethiopia, the contribution of forests to local livelihoods and the national economy as a whole is significant, but is largely unrecorded and hence unrecognized. Forest resources are among several natural resources that have substantial socioeconomic, cultural and ecological importance in Ethiopia. There is a growing awareness of the significance of forest resources and the link between biodiversity, ecosystem services and human well-being (FAO, 2006). Forests are also the source of timber and non-timber forest products. The economic value of Ethiopian forests is not given the proper attention, even if they are sources of ecosystem services, including non-timber forest products that sustain rural livelihoods.

Oromia regional national state is one among the nine regional states of Ethiopia, which is largely dominated by the primary economic sector. Oromia has a total land area of about 363,136 square kilometers, out of which more than $8.5 \%$ of the total land area of the region is covered by forest land, while $59.7 \%$ of the land is covered by bushes and patches of trees (ONRSAB, 2014). In Oromia forest products and the benefits that they provide in the form of wood, food, income and water shed protection play a critical role in enabling people to secure stable and adequate food supply (Hirpassa, 2010). But the economic value of Ethiopian forests in general, and that of Oromia in particular is not given the proper attention, even if they are sources of ecosystem services, including nontimber forest products that sustain rural livelihoods. The assessment of the contribution of forestry sector to the national economy needs due emphasis to propose policy recommendations for the sake of proper management of our forest products. Therefore, the study focuses on the descriptive analysis of the contribution of forest production to national income and challenges associated with forestry accounting in Ethiopia particularly, in the economy of Oromia national regional state.

\section{LITERATURE REVIEW}

According to international Standard Industrial Classifications for all Economic Activities revision 4, forestry and logging division includes the production of round-wood for the forest-based manufacturing industries as well as the extraction and gathering of wild growing non-wood forest products. Besides the production of timber, forestry activities result in products that undergo little processing, such as fire wood, charcoal, wood chips and round-wood used in an unprocessed form (e.g. pit-props, pulpwood etc.). These activities can be carried out in natural or planted forests (United Nations, 2008). 
Silviculture is the branch of forestry dealing with the development and care of forests. Silviculture and other forestry activities can be carried out in natural or planted forests. Silviculture includes activities like growing of standing timber planting, replanting, transplanting, thinning and conserving of forests and timber tracts, bamboo, thatches, growing of coppice, pulpwood, and fire wood, and operation of forest tree nurseries.

Logging is the work of cutting down trees for timber, the trade of cutting, preparing or selling timber. This activity includes Production of round wood for forest-based manufacturing industries, Production of round wood used in an unprocessed form such as pit-props, fence posts, and utility poles, bamboo, thatches, Gathering and production of fire wood and Production of charcoal in the forest using traditional methods.

Gathering of non-wood forest products is also another activity included in the forestry and logging sector in ISIC revision 4. This sector includes activities like: gathering of non-wood forest products and other plants growing in the wild (mushrooms, truffles, berries, nuts, balata and other rubber-like gums, cork, lac and resins, balsams, vegetable hair, eelgrass, acorns, horse chestnuts, mosses and lichens) and Incense \& myrrh, wild fruits, medicinal herbs (Ibid).

Support services to forestry include carrying out part of the forestry operation on a fee or contract basis. It includes forestry service activities and logging service activities. Forestry service activities are like forestry inventories, forest management consulting services, timber evaluation, forest fire fighting and protection, forest pest control. While Logging service activities include transport of $\operatorname{logs}$ within the forest.

\section{METHOD}

To analyze the contribution of agriculture to economic growth, secondary data is used. In doing so, the ten years' time series data (from 1999/2000-2009/10) is collected from the Oromia Bureau of Finance and Economic Development (BoFED) on the forest production subsector. In this study, descriptive analysis is employed using statistical tools such as percentages, tables, and other statistical summaries.

\section{RESULT AND DISCUSSION}

This section presents the time series data collected from Oromia bureau of finance and economic development. The data analysis starts with the description of the contribution of forest products to the GDP of Oromia national regional state and the challenges of forest products.

\section{The contribution of Forest Production to GDP of Oromia}

Oromia is the largest Regional State endowed with forest resources. Previously there was a large coverage of forest in Oromia national regional state. This was because the regional state is endowed by favorable climatic condition for forest resources. The most part of forest coverage in Ethiopia was found in Oromia regional state. 
Table 1. Gross Value Added of forest production and its share in regional GDP of Oromia (000 Birr)

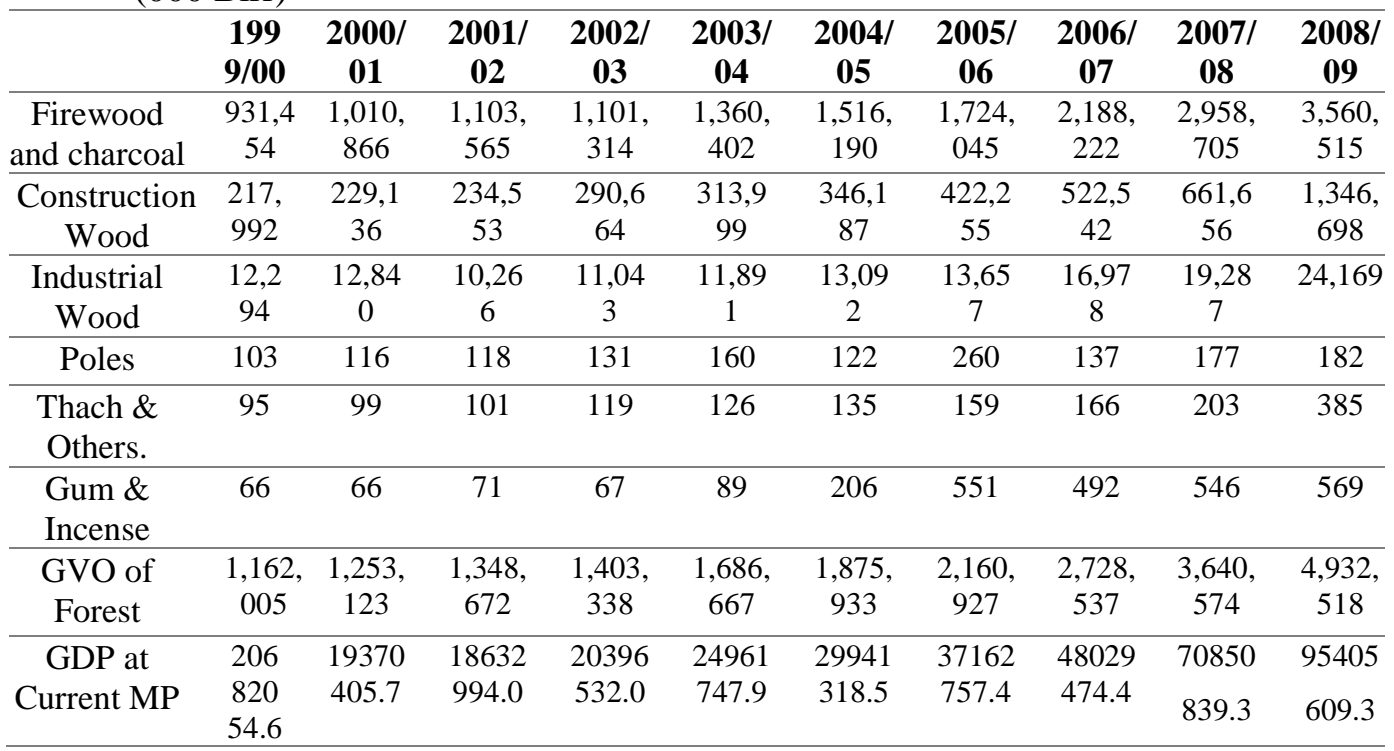

Source: Oromia Bureau of Finance and Economic development (BoFED), 2011

In Oromia, the majority of the population uses forest products for charcoal and fire wood as a fuel for cooking food. In 1999/00 the value of forest product used as charcoal and fire wood was birr 931.45 million. The use of forest as firewood and charcoal increased through time in all the years. The contribution of forest as a firewood and charcoal increased to birr 3.56 billion in the year 2008/09 and became the largest contribution of forest product to the economy.

The forest of Oromia is a source of excellent timber. As a part of developing country, people of Oromia state used forest products as raw materials for construction of houses and buildings. Timber is for construction of houses and production of home furniture. This is the second largest use of forest product in the state, in all the years under consideration. The use of forest as construction material in Oromia was about birr 217.99 million in 1999/00. This value increased to birr 1.35 billion in the year 2008/09. This indicates that there is an increasing trend in the use of forest as construction material each year in the periods under consideration.

Forest products are also used as industrial raw materials in Oromia national regional state. Trees are used in industrial processing and also production of material furniture. In 1999/00 the value of forest products used in industries as raw material was birr 12.29 million. Its value declines in the year 2001/02 to birr 10.27 million but again increased to birr 11.04 million in the year 2002/03. From the year 2002/03 onwards the value of forest products used in industry increased from year to year. In the year 2008/09, the values of forest products used in industry as a raw material increased to birr 24.17 million (see table 1). This is the largest in the years under consideration. This indicates that the use of forests as industrial raw material increases from time to time in Oromia national regional state.

In addition, medicinal plants and trees producing different kinds of gums and incenses grow in abundance. Forest products are also used as poles. But the use of forest for such aspects is not significant as compared to other uses. Though 
the monetary value of forest product as the poles, gums and incenses is very low, it shows an increasing trend each year.

The table result shows that there is an increasing trend in the contribution of forest products in all the years under study. There is a continuous increase in contribution of forest production to the regional gross domestic product of Oromia national regional state in all the years. But, forest production is about onetwentieth of the total regional GDP in 1999/00. That is, it is about birr 1.16 billion, while regional GDP is about birr 20.68 billion in the same year.

The value of forest products was doubled in the year 2005/06 to about birr 2.16 billion. At this time the regional gross domestic product of Oromia was about birr 37.16 billion. It the year 2008/09 the money value of forest product was about birr 4.93 billion while regional GDP of Oromia was about birr 95.4 billion. The gross value of forest output showed an increasing trend in all the years under study. Yearly increase in the value of forest production can be explained in different ways. The first one is that the use of forest products is continuously increasing due to the emergence of different industries using forest as raw materials. The value of forest products also increased due to the inflationary effects that emerged in Ethiopia in most of the years under study along with the increase in the demand of forest products. Because of such reasons, the value of forest products showed an increasing trend in all the years.

\section{Percentage Contribution of Forest Production to GDP of Oromia}

In developing countries like Ethiopia, the livelihood of nations depends largely on primary economic activities like agriculture and forestry production. Forest production is among the economic sectors in Oromia national regional state contributing less to the regional gross domestic product because less emphasis is given to this sector. In 1999/00 production year, forest production contributed about 5.62 percent to the nominal GDP of Oromia. In this year forest production contributed less to GDP as compared to crop and livestock production sectors. It was the least contributor next to fishery production. The percentage contribution of forest in Oromia increased in the year 2000/01. This is due to two different reasons. Firstly, in this production year, the gross value of production of other sectors declined. Secondly, the value of forest output increased, which collectively resulted in the increased percentage contribution of forest product in the year under consideration.

Table 2. The percentage contribution of forest sub-sector and other sectors to GDP of Oromia

\begin{tabular}{ccccccc}
\hline \multirow{2}{*}{ Years } & \multicolumn{6}{c}{ Percentage share in GDP } \\
\cline { 2 - 7 } & Crop & Livestock & Forest & Fishery & Industry & Service \\
\hline $\mathbf{1 9 9 9 / 0 0}$ & 39.05 & 19.12 & 5.62 & 0.099 & 12.99 & 22.73 \\
\hline $\mathbf{2 0 0 0 / 0 1}$ & 30.98 & 22.08 & 6.47 & 0.099 & 14.31 & 25.71 \\
\hline $\mathbf{2 0 0 1 / 0 2}$ & 25.61 & 21.58 & 7.24 & 0.11 & 15.11 & 30.00 \\
\hline $\mathbf{2 0 0 2 / 0 3}$ & 25.45 & 19.14 & 6.88 & 0.13 & 16.31 & 31.95 \\
\hline $\mathbf{2 0 0 3 / 0 4}$ & 30.73 & 18.65 & 6.76 & 0.08 & 15.401 & 28.24 \\
\hline $\mathbf{2 0 0 4 / 0 5}$ & 37.37 & 17.21 & 6.27 & 0.05 & 12.35 & 26.55 \\
\hline $\mathbf{2 0 0 5 / 0 6}$ & 38.85 & 17.067 & 5.81 & 0.04 & 12.04 & 26.03 \\
\hline
\end{tabular}




\begin{tabular}{ccccccc}
\hline \multirow{2}{*}{ Years } & \multicolumn{6}{c}{ Percentage share in GDP } \\
\cline { 2 - 7 } & Crop & Livestock & Forest & Fishery & Industry & Service \\
\hline $\mathbf{2 0 0 6 / 0 7}$ & 41.33 & 16.43 & 5.68 & 0.05 & 10.82 & 25.60 \\
\hline $\mathbf{2 0 0 7} / \mathbf{0 8}$ & 47.39 & 15.45 & 5.14 & 0.13 & 8.75 & 23.07 \\
\hline $\mathbf{2 0 0 8} / \mathbf{0 9}$ & 48.49 & 12.67 & 5.17 & 0.15 & 9.72 & 23.72 \\
\hline Average \% share & $\mathbf{3 6 . 5 3}$ & $\mathbf{1 7 . 9 4}$ & $\mathbf{6 . 1 0}$ & $\mathbf{0 . 0 9 5}$ & $\mathbf{1 2 . 7 8}$ & $\mathbf{2 6 . 3 6}$
\end{tabular}

Source: Computed from data of (BoFED, 2011)

The gross value as well as the percentage contribution of forest output to GDP of Oromia increased in the following production years till 2001/02. This year shows the highest percentage contribution of forest production to the national income of Oromia. Starting from the year 2002/03 to 2008/09 production years the percentage contribution of forest production showed a continuous decline. This is because of the increase in the percentage contribution of other subsectors in agriculture as well as other sectors of the economy. The gross value of forest products increased continuously throughout the whole production period under study, while the percentage share changed depending on the changes in the contribution of other sectors of the economy. On an average, the forest production contributed about 6.10 percent to the total GDP of Oromia national regional state. This is about one twentieth of the gross national income of the regional state.

\section{Challenges in measurement of the contribution of forestry products to GDP in Oromia}

As compared to the other sectors of the economy, forest production is contributing less to the gross domestic product of Oromia national regional state. It is also the least contributor to GDP of Oromia next to fishery production sector. There are some reasons for the low contribution of forestry production to the national income (GDP) of Ethiopia in general, and particularly in case of Oromia. The firstly, there is reduction of forest coverage due to high rate of deforestation. The secondly there exists an inappropriate accounting of forestry products in Ethiopian system of national accounts. The other reason is that there is underestimation in economic value of forest production.

\section{Deforestation}

Historically, Ethiopian forest was facing high rates of deforestation in the past years. Deforestation and land degradation in Ethiopia, however, are impairing the capacity of forests and the land's contribution to food security and provide other benefits such as fuel wood and food (Food and Agriculture Organizaion, 2004). Ethiopians are facing rapid deforestation and degradation of land, clearing for agricultural use, over grazing and exploitation of existing forest for fuel wood and construction materials. High forest areas have been reduced from $40 \%$ century ago to an estimated less than 3\% today (Hirpassa, 2010). High rate of deforestation results in the destruction of major portion of the forest resources in the country. Only some the forest resources still remain in the south and west parts of the Oromia and Southern Ethiopian nations, nationalities and peoples' region. Through time there was a large deforestation and destruction of forest resources. The forest resource is threatened by mismanagement, particularly, 
through fast expansion of mega commercial farms and resettlement programs. Deforestation is among the main challenges making the forest to be low contributor to gross domestic product of Ethiopia in general and the regional state in particular (Mergo, 2014).

Forest degradation in Oromia is also caused by unsustainable consumption of fuel wood and the conversion of forest areas to commercial crops such as coffee by small holders as well as illegal tree harvesting and grazing. The main source of fuel in Oromia is largely wood and charcoal collected from forest trees (ONRS, 2011). This threatens the existence of forest resources in this regional state. Many coffee-producing small holder farmers converted the forest resources into coffee farms. Since there is poor enforcement of law and population growth, migration, and development of road infrastructure, there is high deforestation in Oromia threatening our forest resources. Therefore, deforestation and misuse of forest products become the main causes for the low contribution of forest products to the national income of Oromia.

\section{Inappropriate Accounting of Forestry Sector to the National Income in Ethiopian System of National Accounts}

There are activities to be included in the forestry and logging sector according to ISIC but left unaccounted to GDP in the Ethiopian system of national accounts due to various reasons. For example, from non-wood forest products types of activities, only gums and some of Incense \& myrrh, wild fruits, medicinal herbs are included in the system of national accounts in Ethiopia, while many other non-wood products of the forestry sector are still excluded. This largely affected the contribution of forestry sector to have low share of in the national income (NPC, 2015). In Ethiopian system of national accounts none of the support services related to forest and logging activities are accounted to forestry sector. The contribution of forestry sector to the GDP of Oromia is lower since the country's system of national accounts governing the GDP measurement system of all regional states missed some of the attributes of forestry sector in calculation of GDP. This is so because there is difficulty in getting data of this attributes of forestry sector.

Apart from the above there are also some forest attributes accounted in different economic sectors due to the problem of production boundary definition set by ISIC. Among these some of them are:

Forest Attributes assigned to Crop Farming sector of ISIC: Managed production of any of non-wood forest products (except growing of cork trees), growing of Christmas trees, Operation of tree nurseries, Production of wood chips and particles, growing of mushrooms or truffles and growing of berries or nuts. These activities are among the forestry sector but accounted to crop farming sector due to the problem of boundary definition by the international standard industrial classification in all economic activities (ISIC). This boundary definition problem increases the contribution of crop sector but understates the values of forestry sector in the GDP of the regional state.

Forest-based manufacturing Industries: Manufacture of wood and of products of wood and cork, except furniture; manufacture of articles of straw and plaiting and Manufacture of paper and paper products. ISIC also assigned the above attributes of forestry sector to the manufacturing sector while its 
appropriate classification was forestry and logging activities. This overstates the share of manufacturing sector and understates the forestry sector contribution to the national income.

The Supply Side of forestry sector: Production of field crops (coffee cultivation etc.) and Animal fodder, and extraction of minor and major minerals in forests, included in agriculture and mining sectors respectively. Trading in Forestry and Logging related activities, Public Administration Services, Entertainment \& Recreation etc. are also included in other sectors rather than accounting them as the Contribution of forestry sector to the national income. This creates huge deviation in the accounted contribution and the actual contribution of forestry and logging sector to the GDP.

The Use Side of forestry sector: Forestry contribution to Consumption Expenditure, Gross Capital Formation (Investment), Export Earnings, Domestic Savings, Domestic Revenue is not accounted to the forestry sector leading to insignificant contribution of forestry sector to the GDP. The forest sector contribution in other microeconomic (households and Firms) and macroeconomic spheres is also not properly accounted to the forestry sector. The role of forestry sector to Environmental protection and conservation of natural resources as well as forestry role in sustainability of the environmental resources is also in question. Because none of these attributes of forest sector is accounted as contributions of forest sector to the national income of Ethiopia in general and in Oromia national regional state in particular. This and the above-mentioned reasons are the causes for the low contribution of forestry sector to the gross domestic product of Oromia.

\section{Underestimation of Economic Value of Forest Production in GDP}

Besides being a source of fuel wood, timber, medicine, and gum, forests are useful in the conservation of water and soil. In this case, forest is the main indirect contributor to the agricultural production. Forest attracts rain to the area. That is why it usually rains in the area where there is more forest. Forest is also used as shelter for wildlife resources. They also have an important aesthetic value.

World Resource Institute (WRI, 2007) stated the contribution of forest and trees to agricultural production as "maintain the soil and water for agricultural production, particularly in upland water sheds, by reducing erosion and moderating streams flow, restore soil fertility in shifting agriculture; increase farm crop yields by $20-30 \%$ in arid and semiarid areas by slowing wind and increasing soil moisture; increase soil nitrogen content through use of leguminous nitrogen fixing tree species; and provide a significant proportion of livestock feed requirements especially, in upland and semiarid regions. Trees are also essential sources of fodder for livestock resources which has positive effects on the livestock production. Virtually all forests everywhere have environmental function, but the nature of that function varies. The forest production has both direct and indirect contribution to the national income of the regional state which is difficult to incorporate in the national income account. But none of the abovementioned attributes of forestry sector are is not accounted to the sector in the proper manner so as to show the actual contribution of forest to the GDP of countries of the world in general and that of Oromia national regional state in particular. 
Economic benefits of ecosystems extend far beyond exploiting them for resources. The true value of the planet's ecosystems is frequently misrepresented, if not invisible, in markets and economic decision-making (Hummel, 1984). But the real economies that underpin our societies are themselves fundamentally rooted in the natural world. In a forest, the value of timber can be significant and obvious on the open market. But the capacity of the forest to prevent soil erosion in surrounding agricultural land is not so easily or readily accounted for. But its capacity to sequester carbon and help prevent climate change goes unappreciated in economic terms because of the difficulty to measure its real economic value in monetary terms. Grasslands can be an economic foundation of communities, both for their arable land and as a draw for wildlife-based tourism. Without awareness of the true value of these ecosystem services, and how GDP depends on the health of ecosystems, we are bound to continue to exploit them in an unsustainable way (Dervis, 2010). Thus, such contributions of forest are not included in the calculation of GDP. This indicates that the actual economic value of forestry is not accounted properly in the national income accounts. That is why the measure of economic value of forest production is understated and does not show the actual contribution of forestry sector to national income accounts

\section{CONCLUSION}

The above analysis shows that during ten years, the market value of forest production and its contribution to the GDP of Oromia showed continuous increment. On an average, forest production contributed about 6.10 percent to the GDP of Oromia national regional state. Forest sector is contributing less to the gross domestic product of Oromia compared to other sectors. That is, forestry sector is the second least contributor to the gross domestic product of Oromia, next to fishery production. In Oromia, the majority of the population use forest products as a source of fuel. Forest products are also used for production of timber and source of construction materials. The gross value of forest products showed an increasing trend in all the years under study. The use of forest products is continuously increasing due to the emergence of different industries using forest as raw materials. The gross value as well as the percentage contribution of forest output to GDP of Oromia increased in the following production years till 2001/02 and it showed the highest percentage contribution of forest production to GDP in the same year. Among the reasons for the low contribution of forest production to GDP of Oromia national regional state, the reduction of forest coverage due to deforestation is the main one. There is high rate of deforestation and misuse of forest products in Oromia in recent years reducing the availability of forestry products. There are many attributes of forestry products left unaccounted in the GDP of Oromia national regional state, due to difficulty of getting data. Some of these forest attributes are grouped under forestry and logging sector in ISIC, but unaccounted in Ethiopian system of national accounts due to different reasons, while some are accounted into other sectors of the economy due to the boundary definition problem of ISIC. The economic value of forest production is also underestimated in the accounts of gross domestic product of Oromia national regional state. The economic value of forestry sector is beyond the one accounted in the calculation of gross domestic product of the regional state. The above listed 
and other factors affect the forest production to be the second least contributor to the gross domestic product in Oromia.

In the rapidly growing GDP of Oromia national regional state forest production is least contributor. But forest production is useful beyond the monetary value accounted in GDP of Oromia. Therefore, with the above understanding, and the need to appreciate the existing constraints and opportunities within forest production, Bureau of finance and economic development of Oromia should re-examine how economic growth can be achieved in the state. Particularly, the way economic growth could be propelled through the contribution of forest production, taking awareness of the existing capacity to increase growth and alleviate poverty. This process will be performed through the improvement of performance of GDP and the contribution of Forestry sector in the economy. Resources must be directed into areas where there is adequate evidence of potential growth. This will be through enhancement of conservation and wise use of forest resources in Oromia so that it can contribute more to the domestic income, directly in monetary terms and indirectly through its contribution to other sectors of the economy. It is also recommended that the concerned body need to incorporate the real economic value of the forest resources in the system of national accounts in Ethiopia in general and particularly for Oromia national regional state. This will give more credit to forest sector, and increase awareness in the society, so as to make a proper use of forest resources and boost its contribution to the GDP of Oromia national regional state.

\section{REFERENCES}

BoFED. (2011). Oromia National Regional State Regional Economic Accounts Statistics. PART- IV 1992-2002 EFY Estimates. Addis Ababa, Ethiopia: Oromia Bureau Of Finance \& Economic Development.

Dervis, K. (2010). The World Economy and Development. Paper presented on 25th Nov 2010. Paris, France: Paris School of Economics (PSE).

FAO. (2006). Forestry Contribution to National Economy and Trade in Ethiopia, Kenya and Uganda. By, By Kilawe, E. and Habimana, D. Addis Ababa, Etiopia: Food and Agriculture Organization.

Food and Agriculture Organizaion. (2004). Contribution of the Forestry Sector to

National Economies, 1990-2011, by Arvydas Lebedys and Yanshu Li.

Finance Working Paper FSFM/ACC/09. Rome, Italy: Food and Agriculture Organization.

Hirpassa, T. (2010). An Assessment of Forest Resource Conservation and Development Strategy in the Case of Ameya Woreda South West Shewa

Zone, Oromia Regional State. Addis Ababa, Ethiopia: Addis Ababa University.

Hummel, E. A. (1984). Forest Policy: A Contribution to Resource Development, Martines Nijhoff/. Boston, USA: Dr. W.Jank Publishers.

Kamal, M. K. (2010). Forest Restoration And Rehabilitation In Bangladesh. Chittagong, Bangladesh: Chittagong University.

Mergo, L. (2014). Indigenous Forest Management among the Oromo of Horro Guduru, Western Ethiopia. Jimma, Ethiopia: Jimma University. 
NPC. (2015). An economic development strategy for Ethiopia: A comprehensive guidance \& a development strategy for the future. . Addis Ababa, Ethiopia: National Plan Commission of Ethiopia.

ONRS. (2011). Program of Plan on Adaptation to Climate Change. Addis Ababa, Ethiopia: Oromiya National Regional State.

ONRSAB. (2014). Agricultural Transformation Agenda of Oromia Region: Cooperatives Unions as Key Players. Presented On International Conference in Dember 2014. Addis Ababa, Ethiopia: Oromia National Regional State Agriculture Bureau.

Tietenberg et al. (2012). Environmental and natural resource Economics, 9th Edition. Boston: Pearson Education, Inc.

United Nations. (2008). International Standard Industrial Classification of all Economic Activities Revision 4. New York: United Nations Department of Economic and Social Affairs, Statistics Division.

WRI. (2007). Securing Rights, Combating Climate Change. How Strengthening Community Forest Rights Mitigates Climate Change. World Resource Institute. 